\title{
Maternal Dietary Intake of Essential Fatty Acids Affects Adipose Tissue Growth and Leptin mRNA Expression in Suckling Rat Pups
}

\author{
MARINA KOROTKOVA, BRITT GABRIELSSON, LARS-ÅKE HANSON, AND \\ BIRGITTA STRANDVIK \\ Departments of Pediatrics [M.K., B.S.] and Clinical Immunology [L.-A.H.], Research Centre for \\ Endocrinology and Metabolism, and Department of Internal Medicine [B.G.], Göteborg University, SE \\ 41685 Göteborg, Sweden
}

\begin{abstract}
ABS
We have previously shown that maternal intake of essential
fatty acids during late gestation and lactation affects the level of
serum leptin in pups. The aim of the present study was to
investigate the effect of dietary essential fatty acids on leptin
content in the milk of rat dams and leptin expression in white
adipose tissue of pups during the suckling period. During late
gestation and throughout lactation, rats were fed a control or an
essential fatty acid-deficient (EFAD) diet. Milk of the EFAD
dams contained more saturated and less polyunsaturated fatty
acids compared with the control dams. Milk leptin levels were
higher in the EFAD dams than in the control dams at 3 wk of
lactation. The weight of inguinal white adipose tissue depots and
the serum leptin levels of the EFAD pups were significantly
lower than in the control pups during the whole suckling period.
In addition, semiquantitative reverse transcriptase-PCR analysis
of leptin mRNA levels in inguinal white adipose tissue showed a
reduction in the EFAD pups compared with the control pups at 3
wk of age. We conclude that maternal dietary essential fatty acid
\end{abstract}
Nutritional factors during fetal life and infancy have longterm effects on the future health of animals and humans (1). Reduced growth in early life, a potential marker of nutritional status, is a risk factor for adult asthma (2), impaired glucose tolerance, type 2 diabetes, and high blood pressure (3). A mild deficiency of dietary EFA may be one of the causes for low birth weight of newborns (4). Deficiency of EFA has been observed in parenterally fed preterm infants (5) and in infants born after multiple pregnancies (6). Dietary deficiency of EFA in early life may have long-term effects on the development of the neonates via substrate availability or hormone-associated mechanisms.

Received December 3, 2001; accepted February 28, 2002

Correspondence and reprint requests: Marina Korotkova, M.D., Department of Pediatrics, Göteborg University, SE 41685 Göteborg, Sweden; e-mail: Marina. Korotkova@vgregion.se

Supported by grants from the Swedish Medical Research Council (4995), Göteborg Masonic Order and the Royal Academy of Science. intake affects serum leptin levels in pups by regulating both the amount of adipose tissue and the leptin mRNA expression.

(Pediatr Res 52: 78-84, 2002)

\[ \text { Abbreviations } \]
EFA, essential fatty acids
FA, fatty acids
PL, phospholipids
EFAD, essential fatty acid-deficient
SFA, saturated fatty acids
MUFA, monounsaturated fatty acids
PUFA, polyunsaturated fatty acids
LCPUFA, long-chain polyunsaturated fatty acids
WAT, white adipose tissue.
RT, reverse transcriptase
EtBr, ethidium bromide
USI, unsaturated index

It is known that the $o b$ gene product leptin is expressed early in postnatal life in humans and rats $(7,8)$. In addition to regulation of food intake and energy expenditure, leptin is involved in a variety of physiologic processes (9). Indication that leptin may play an important role, especially during intrauterine and neonatal development, is shown by leptin production in the placenta (10), fetal tissues (7), mammary glands (11), and neonatal adipose tissue (12). Several factors regulate serum leptin levels, including hormones (9), cytokines (13), and dietary components such as carbohydrates (14), PUFA (15), and micronutrients (16). Variation in the type of diet during pregnancy and lactation might therefore significantly modulate fetal and neonatal growth and development by leptinassociated mechanisms. It has been shown that quantity and quality of the dietary fat of the mothers affect the serum leptin levels in the offspring $(17,18)$. Deficiency in the intake of EFA of the mothers depresses serum leptin levels in suckling rat pups (18). The EFA deficiency might affect adipocyte differ- 
entiation or adipocyte capacity to produce leptin. In addition, it has recently been shown that leptin is present in both human and mouse milk $(11,19)$. The significantly decreased serum leptin levels noted in the pups from EFAD dams may also be explained by lower consumption of leptin via the mother's milk.

The aim of the present study was to investigate whether low leptin levels in pups of rat dams fed an EFAD diet were caused by low leptin levels in the mother's milk or altered leptin production in the pups. Both the amount of adipose tissue and the leptin mRNA expression were studied in the offspring.

\section{METHODS}

Animals. Pregnant Sprague-Dawley rats (BK Universal, Stockholm, Sweden) were received on d 7 of gestation and housed individually under constant conditions of humidity $(70-80 \%)$, temperature $\left(22-25^{\circ} \mathrm{C}\right)$, and light (12-h light and dark cycle) with food and water available ad libitum. Ten days before delivery, the rats were assigned to one of two groups ( $n$ =9) receiving either a control or an EFAD diet. Litter size was adjusted to 10 pups per litter. Randomized female pups (one from each litter) were used for each time point $(n=9)$. Body weight and length of pups were recorded every week. The animals were killed by decapitation in the morning ( $0900-$ $1100 \mathrm{~h}$ ) at 1, 2, or 3 wk of age. Truncal blood was collected, and sera were kept frozen $\left(-20^{\circ} \mathrm{C}\right)$ until analyses of leptin and FA composition of serum phospholipids. Pairs of s.c. (inguinal) fat pads were removed, weighed, placed into the RNAlater (Ambion, Austin, TX, U.S.A.), and stored at $-20^{\circ} \mathrm{C}$ until analysis by RT-PCR.

Milk samples were collected from dams $(n=6-9)$ at 1 and $3 \mathrm{wk}$ of lactation. After separation from the pups for $30 \mathrm{~min}$, dams were anesthetized i.p. with pentobarbital ( $35 \mathrm{mg} / \mathrm{kg}$ body weight) and injected i.p. with 4 IU of oxytocin (Sigma Chemical Co., St. Louis, MO, U.S.A.) to stimulate milk flow. Milking was initiated 5 min after oxytocin injection, and milk was collected by hand expression. The milk samples were stored at $-20^{\circ} \mathrm{C}$ until analyses of leptin and of FA composition of total lipids.

The study was approved by the Animal Ethics Committee of Göteborg University.

Diets. The dams were fed one of two powdered diets (AnalyCen, Lidköping, Sweden) for the last $10 \mathrm{~d}$ of gestation and throughout lactation. The diets differed only by lipid composition: $7 \%$ soybean oil for the control diet and 7\% hydrogenated lard for the EFAD diet (Table 1). The total metabolizable energy for the diets was $13.9 \mathrm{MJ} / \mathrm{kg}$.

FA analysis. Total lipids of serum and milk were extracted according to Folch and Sloane-Stanley (20). Serum total lipids were fractionated on a single Sep-Pak aminopropyl cartridge (Waters Corp., Milford, MA, U.S.A.), and the fraction of PL was analyzed. Milk total lipids were not fractionated. The FA methyl esters were separated by capillary gas-liquid chromatography in a Hewlett-Packard 6890 gas chromatograph according to the method described previously (18). The separation was recorded with HP GC Chem Station software (HP GC, Wilmington, DE, U.S.A.). C21:1 was used as an internal
Table 1. Composition of control and EFAD diets

\begin{tabular}{lcc}
\hline \multicolumn{1}{c}{ Component } & $\begin{array}{c}\text { Control } \\
(\mathrm{wt} \%)\end{array}$ & $\begin{array}{c}\text { EFAD } \\
(\mathrm{wt} \%)\end{array}$ \\
\hline Casein & 20.0 & 20.0 \\
Potato starch & 54.0 & 54.0 \\
Glucose & 10.0 & 10.0 \\
Cellulosal flour & 4.0 & 4.0 \\
Mineral mix* & 4.0 & 4.0 \\
Vitamin mix $\dagger$ & 1.0 & 1.0 \\
Soybean oil & 7.0 & \\
Hydrogenated lard & & 7.0 \\
Fatty acids (mol\%) & & \\
$12: 0$ & 0.1 & 0.2 \\
$14: 0$ & 0.2 & 0.3 \\
$16: 0$ & 10.8 & 5.4 \\
$16: 1$ & 0.1 & 0 \\
$18: 0$ & 9.0 & 41.0 \\
$18: 1$ & 18.9 & 0.7 \\
$18: 2$ & 45.7 & 0 \\
$20: 0$ & 1.7 & 9.9 \\
$18: 3$ & 8.1 & 0 \\
$20: 2$ & 0.1 & 0 \\
$22: 0$ & 5.0 & 41.4 \\
$24: 0$ & 0.2 & 1.2 \\
\hline
\end{tabular}

* Salt mixture containing (wt\%): $\mathrm{KH}_{2} \mathrm{PO}_{4}$ (34.1); $\mathrm{CaCO}_{3}$ (35.9); $\mathrm{KCl}$ (2.5); $\mathrm{NaCl}$ (18); $\mathrm{MgSO}_{4} \cdot \mathrm{H}_{2} \mathrm{O}$ (5.1); $\mathrm{FeC}_{6} \mathrm{H}_{5} \mathrm{O}_{7} \cdot 5 \mathrm{H}_{2} \mathrm{O}$ (3.3); $\mathrm{MnO}$ (0.27); $\mathrm{Cu}_{2} \mathrm{C}_{6} \mathrm{H}_{4} \mathrm{O}_{7} \cdot 2.5 \mathrm{H}_{2} \mathrm{O}(0.06) ; \mathrm{Zn}_{3}\left(\mathrm{C}_{6} \mathrm{H}_{5} \mathrm{O}_{7}\right)_{2} \cdot 2 \mathrm{H}_{2} \mathrm{O}(0.04) ; \mathrm{CoCl}_{2} \cdot 6 \mathrm{H}_{2} \mathrm{O}$ (0.002); $\mathrm{KAl}\left(\mathrm{SO}_{4}\right)_{2} \cdot 2 \mathrm{H}_{2} \mathrm{O}(0.008) ; \mathrm{NaF}(0.025) ; \mathrm{KIO}_{3}(0.009) ; \mathrm{Na}_{2} \mathrm{~B}_{4} \mathrm{O}_{7} \cdot$ $10 \mathrm{H}_{2} \mathrm{O}(0.002) ; \mathrm{Na}_{2} \mathrm{SeO}_{3} \cdot 5 \mathrm{H}_{2} \mathrm{O}(0.001) ; \mathrm{Na}_{2} \mathrm{MoO}_{4} \cdot 2 \mathrm{H}_{2} \mathrm{O}(0.001)$.

$\dagger$ Vitamin mixture containing: Vit A, $11.9 \mathrm{IE} / \mathrm{g}$; Vit $\mathrm{D}_{3}, 1.5 \mathrm{IE} / \mathrm{g}$; Vit $\mathrm{B}_{1}, 4$ $\mu \mathrm{g} / \mathrm{g}$; Vit $\mathrm{B}_{2}, 12 \mu \mathrm{g} / \mathrm{g}$; Vit $\mathrm{B}_{6}, 5 \mu \mathrm{g} / \mathrm{g}$; Ca-pantotenate $45 \%, 11 \mu \mathrm{g} / \mathrm{g}$; niacin, $40 \mu \mathrm{g} / \mathrm{g} ; V_{\text {Vit }} \mathrm{B}_{12}, 0.02 \mu \mathrm{g} / \mathrm{g}$; Vit $\mathrm{K}_{3}, 7.75 \mu \mathrm{g} / \mathrm{g}$; biotin $2 \%, 3 \mu \mathrm{g} / \mathrm{g} ;$ Vit C, 500 $\mu \mathrm{g} / \mathrm{g}$; inositol, $30 \mu \mathrm{g} / \mathrm{g}$; Vit E, $42 \mu \mathrm{g} / \mathrm{g}$; choline chloride $50 \%, 1 \mathrm{mg} / \mathrm{g}$; folic acid, $0.5 \mu \mathrm{g} / \mathrm{g}$.

standard, and the FA methyl esters were identified by comparison with retention times of pure reference substances (Sigma Aldrich Sweden AB, Stockholm, Sweden). The ratio of 20:3(n-9) to arachidonate greater than 0.4 was used as the biochemical criterion of EFA deficiency (21).

Analysis of leptin. Leptin concentrations in serum and milk were measured by a rat leptin RIA (Linco Research Ltd., St. Charles, MO, U.S.A.). All samples were analyzed in duplicates in the same assay. The intraassay coefficient of variation at $0.25 \mathrm{ng} / \mathrm{mL}$ was $2.4 \%$, and at $20 \mathrm{ng} / \mathrm{mL}, 1.6 \%$. Milk samples were thawed at $37^{\circ} \mathrm{C}$ and vortexed vigorously before pipetting. The samples were diluted in assay buffer (1:2 to $1: 5)$ before sonication (five bursts, $5 \mathrm{~s} /$ burst with cooling on ice between each burst, $80 \%$ power) to ensure homogeneous samples. To control for possible matrix effects in the individual milk samples, each sample was divided into three tubes, and a standard addition procedure was used by adding 1 and $1.8 \mathrm{ng}$ of leptin, respectively, to the second and third tubes. The original leptin content was then calculated using linear regression. An effect of nonspecific background in the milk on leptin data was evaluated by comparing added leptin with measured leptin. There was a matrix effect in milk in both diet groups, and we therefore used the leptin values calculated from the standard addition procedure. The intraassay coefficient of variation for the analysis of leptin milk was $10.2 \%$.

RNA extraction and analysis by RT-PCR. Total RNA was isolated from the adipose tissue of each individual rat with the 
RNeasy Mini Kit (QIAGEN, Valencia, CA, U.S.A.) and treated with DNase (DNA-free, Ambion) according to the manufacturer's instructions. The concentration of RNA was determined spectrophotometrically $\left(\mathrm{OD}_{260}\right)$, and its integrity was verified by agarose gel electrophoresis, with visualization by EtBr staining. Synthesis of cDNA was performed using 0.7 $\mu \mathrm{g}$ of total RNA and 3.3 $\mu \mathrm{M}$ random hexamers (Pharmacia Biotech, Uppsala, Sweden) in a solution containing $1 \times$ First Strand buffer (Life Technologies, Gaithersburg, MD, U.S.A.), dNTPmix (Ultrapure dNTP Set, Pharmacia Biotech), RNaseinhibitor (1 U/ $\mu \mathrm{L}$, rRNasin, Promega, Madison, WI, U.S.A.), and reverse transcriptase $(13.3 \mathrm{U} / \mu \mathrm{L}$, Superscript II RT, Life Technologies). The mixture was incubated at room temperature for $10 \mathrm{~min}$ and at $42^{\circ} \mathrm{C}$ for $60 \mathrm{~min}$ followed by $10 \mathrm{~min}$ at $70^{\circ} \mathrm{C}$.

Multiplex relative RT-PCR was used for the analysis of differences in mRNA abundance. The cDNA was amplified by PCR using specific primers for the rat leptin cDNA (22). The primer pairs, 5' CCT GTG GCT TTG GTC CTA TCT G 3' (nucleotides 87-108, GenBank accession number D4582) and 5' AGG CAA GCT GGT GAG GAT CTG 3' (nucleotides 310-330) generated a single 244-bp product. QuantumRNA $18 \mathrm{~S}$ internal standard (Ambion) was used as an internal control and generated a single 489-bp product. The PCR reaction was performed in a final volume of $50 \mu \mathrm{L}$ with $2 \mu \mathrm{L}$ of cDNA product, $1 \times$ PCR buffer, $2.0 \mathrm{mM} \mathrm{MgCl} 2,0.4 \mu \mathrm{M}$ each primer, $0.2 \mathrm{mM}$ each dNTP, and 1.25 U AmpliTaqGold (Applied Biosystems, Foster City, CA, U.S.A.). PCR was performed using the GeneAmp PCR System 9600 and the following conditions: $94^{\circ} \mathrm{C}(12 \mathrm{~min})$ for one cycle, $94^{\circ} \mathrm{C}(30 \mathrm{~s}), 60^{\circ} \mathrm{C}(30$ s), $72^{\circ} \mathrm{C}(30 \mathrm{~s})$ for 30 cycles, and $72^{\circ} \mathrm{C}(7 \mathrm{~min})$. The negative control consisted of omission of the RT for each sample, which resulted in no bands after RT-PCR.
The PCR products were separated on $2 \%$ EtBr agarose gel and subsequently visualized and quantified using IPLab Gel Scientific Image processing (Signal Analitics, Vienna, VA, U.S.A.). The intensity obtained for leptin amplicon was related to that of $18 \mathrm{~S}$ band in each individual sample.

Statistical analysis. Data were analyzed using MannWhitney $U$ test and Wilcoxon signed-rank test. The EFAD-fed animals were compared with the controls at each stage of the treatment. Values are given as mean $\pm \mathrm{SD}$ if not otherwise indicated. A value of $p<0.05$ was considered statistically significant.

\section{RESULTS}

FA composition of total milk lipids and serum PL. Rats fed the control diet produced milk containing 40-50\% SFA, 20\% MUFA, and 30\% PUFA (Table 2). Feeding the EFAD diet to lactating animals induced marked changes in the total milk lipid FA composition already after the first week of lactation; the levels of SFA were increased up to $75-78 \%$, and the levels of PUFA were decreased to 5\%, whereas the concentrations of MUFA were unchanged. Starting at wk 1 the contents of linoleic 18:2(n-6), $\gamma$-linolenic 18:3(n-6), eicosadienoic 20:2(n6), arachidonic 20:4(n-6), and $\alpha$-linolenic 18:3(n-3) acids were significantly decreased, with a compensatory rise in the levels of saturated lauric 12:0, myristic 14:0, palmitic 16:0, and stearic 18:0 acids and palmitoleic 16:1(n-7) acid. The USI was decreased four times in the EFAD group compared with the control group. Feeding the EFAD diet resulted in further changes of the FA composition of milk total lipids after $3 \mathrm{wk}$ of lactation (Table 2). Moreover, at this time the 22:6(n-3) FA levels were significantly decreased along with an accumulation of mead acid 20:3(n-9) in the EFAD group compared with the

Table 2. Total lipid FA composition of milk from control and EFAD rats at 1 and 3 wk of lactation

\begin{tabular}{|c|c|c|c|c|}
\hline \multirow{2}{*}{$\begin{array}{l}\text { Fatty acids } \\
(\mathrm{mol} \%)\end{array}$} & \multicolumn{2}{|c|}{ Control diet } & \multicolumn{2}{|c|}{ EFAD diet } \\
\hline & $1 \mathrm{wk}$ & $3 \mathrm{wk}$ & $1 \mathrm{wk}$ & $3 \mathrm{wk}$ \\
\hline $12: 0$ & $9.5 \pm 1.4$ & $9.2 \pm 4.5$ & $12.1 \pm 1.8^{*}$ & $16.8 \pm 2.2 \dagger$ \\
\hline $14: 0$ & $10.4 \pm 1.6$ & $6.4 \pm 1.7$ & $16.6 \pm 2.1 \dagger$ & $18.2 \pm 3.1 \dagger$ \\
\hline $16: 0$ & $25.5 \pm 2.6$ & $20.5 \pm 2.7$ & $43.4 \pm 6.0 \dagger$ & $33.1 \pm 1.4 \dagger$ \\
\hline $16: 1 n-7$ & $0.63 \pm 0.16$ & $1.2 \pm 0.6$ & $1.6 \pm 0.4 \dagger$ & $2.3 \pm 1.0 *$ \\
\hline $18: 0$ & $5.0 \pm 0.5$ & $5.8 \pm 0.6$ & $5.8 \pm 0.7^{*}$ & $6.2 \pm 0.9$ \\
\hline $18: 1 n-9$ & $17.7 \pm 1.5$ & $20.5 \pm 1.9$ & $14.7 \pm 4.0$ & $19.8 \pm 5.4$ \\
\hline $18: 2 n-6$ & $24.7 \pm 2.3$ & $29.2 \pm 3.0$ & $3.3 \pm 2.9 \dagger$ & $1.4 \pm 0.5 \dagger$ \\
\hline $18: 3 n-6$ & $0.32 \pm 0.08$ & $0.20 \pm 0.06$ & $0.04 \pm 0.02 \dagger$ & $0.0 \pm 0.0 \dagger$ \\
\hline $20: 0$ & $0.20 \pm 0.0$ & $0.22 \pm 0.04$ & $0.11 \pm 0.03 \dagger$ & $0.13 \pm 0.05 \dagger$ \\
\hline $18: 3 n-3$ & $1.9 \pm 0.2$ & $2.4 \pm 0.5$ & $0.11 \pm 0.09 \dagger$ & $0.07 \pm 0.05 \dagger$ \\
\hline $20: 2 n-6$ & $1.0 \pm 0.1$ & $0.82 \pm 0.21$ & $0.52 \pm 0.47 *$ & $0.10 \pm 0.0 \dagger$ \\
\hline $20: 3 n-9$ & $0.07 \pm 0.05$ & $0.10 \pm 0.0$ & $0.12 \pm 0.04$ & $0.50 \pm 0.13 \dagger$ \\
\hline $20: 4 n-6$ & $1.7 \pm 0.7$ & $1.9 \pm 0.7$ & $0.64 \pm 0.37 \dagger$ & $0.57 \pm 0.31 \dagger$ \\
\hline $24: 1 n-9$ & $0.44 \pm 0.29$ & $0.58 \pm 0.26$ & $0.28 \pm 0.08$ & $0.20 \pm 0.06 \dagger$ \\
\hline $22: 6 n-3$ & $0.36 \pm 0.18$ & $0.37 \pm 0.10$ & $0.29 \pm 0.14$ & $0.12 \pm 0.04 \dagger$ \\
\hline $18: 1 n-9 / 18: 2 n-6$ & $0.72 \pm 0.05$ & $0.71 \pm 0.11$ & $6.9 \pm 3.4 \dagger$ & $17.2 \pm 8.4 \uparrow$ \\
\hline $20: 3 n-9 / 20: 4 n-6$ & $0.04 \pm 0.03$ & $0.06 \pm 0.02$ & $0.23 \pm 0.10 \dagger$ & $1.2 \pm 0.8 \dagger$ \\
\hline $20: 4 n-6 / 22: 6 n-3$ & $5.3 \pm 1.4$ & $5.2 \pm 0.6$ & $2.2 \pm 0.5 \dagger$ & $5.3 \pm 3.3$ \\
\hline SFA & $51.0 \pm 4.4$ & $42.5 \pm 3.1$ & $78.2 \pm 7.7$ & $74.7 \pm 5.9$ \\
\hline UFA & $49.1 \pm 4.4$ & $57.5 \pm 3.3$ & $21.9 \pm 7.5$ & $25.4 \pm 5.9$ \\
\hline USI & $1.72 \pm 0.35$ & $2.34 \pm 0.27$ & $0.40 \pm 0.22$ & $0.39 \pm 0.10$ \\
\hline
\end{tabular}

Values are mean \pm SD. USI is calculated as ratio $\Sigma(\mathrm{mol} \%$ each UFA $\times$ number of double bonds of the same FA)/SFA.

Results with * and $\dagger$ are significantly different, $p<0.05$ and $p<0.005$, respectively, from control values. 
control pups. USI was six times lower in the EFAD group compared with the control animals.

There were significant changes in the EFA composition in the sera of pups of the EFAD group at 3 wk of age compared with the control group. The ratio of 20:3(n-9) to 20:4(n-6) in the EFAD group was $1.1 \pm 0.5$ compared with $0.0 \pm 0.0$ in the control group. The deficiency was also expressed in an increased 18:1/18:2 ratio, being $3.2 \pm 1.3$ in the EFAD group compared with $0.2 \pm 0.0$ in the control group (Table 3 ).

Body weight, length, and adipose tissue weight. The mean body weight and length of the pups receiving the EFAD diet did not differ from those of the control pups at 1 and 2 wk of age, but were significantly reduced compared with the control pups before weaning at $3 \mathrm{wk}$ of age (Table $4)$. The weight of s.c. (inguinal) WAT of the pups gradually increased with age, but was significantly $(p<0.05)$ lower during the suckling period in pups from the EFAD dams. The weight of the inguinal WAT relative to body weight was significantly lower among the EFAD pups compared with the control pups at 1-2 wk of age, but was similar at $3 \mathrm{wk}$ of age (Table 4).

There were no differences in mean body weight between control and EFAD dams $(271 \pm 31$ versus $296 \pm 21 \mathrm{~g}$ at $1 \mathrm{wk}$ and $284 \pm 26$ versus $306 \pm 28 \mathrm{~g}$ at 3 wk of lactation, respectively).

Leptin levels in serum and milk. Feeding dams with the EFAD diet affected the serum leptin levels in the suckling pups already from the first week of suckling and up to weaning. The serum leptin concentrations in the control pups during this period were significantly higher than those in the EFAD group (Table 4). The milk leptin levels in the lactating dams fed the control diet decreased significantly from $3.2 \pm 1.1 \mathrm{ng} / \mathrm{mL}$ at 1

Table 3. Serum PL FA composition of the control and EFAD pups at 3 wk of age

\begin{tabular}{lcr}
\hline \multicolumn{1}{c}{$\begin{array}{c}\text { Fatty acids } \\
\text { (mol\%) }\end{array}$} & Control diet & EFAD diet \\
\hline $12: 0$ & $0.8 \pm 0.2$ & $1.1 \pm 0.2 *$ \\
$14: 0$ & $1.4 \pm 0.2$ & $3.0 \pm 0.3 \dagger$ \\
$16: 0$ & $23.0 \pm 0.9$ & $30.0 \pm 1.2 \dagger$ \\
$16: 1 \mathrm{n}-7$ & $0.2 \pm 0.1$ & $1.6 \pm 0.4 \dagger$ \\
$18: 0$ & $22.6 \pm 1.0$ & $19.5 \pm 0.9 \dagger$ \\
$18: 1 \mathrm{n}-9$ & $4.5 \pm 0.5$ & $20.1 \pm 3.5 \dagger$ \\
$18: 2 \mathrm{n}-6$ & $26.8 \pm 1.4$ & $6.9 \pm 1.9 \dagger$ \\
$18: 3 \mathrm{n}-6$ & $0.10 \pm 0.0$ & $0.11 \pm 0.03$ \\
$20: 0$ & $0.24 \pm 0.05$ & $0.15 \pm 0.05^{*}$ \\
$18: 3 \mathrm{n}-3$ & $0.32 \pm 0.07$ & $0.06 \pm 0.05 \dagger$ \\
$20: 2 \mathrm{n}-6$ & $0.54 \pm 0.07$ & $0.26 \pm 0.05 \dagger$ \\
$20: 3 \mathrm{n}-9$ & $0.08 \pm 0.04$ & $6.3 \pm 1.2 \dagger$ \\
$22: 0$ & $0.66 \pm 0.05$ & $0.47 \pm 0.19 *$ \\
$20: 4 \mathrm{n}-6$ & $14.1 \pm 0.8$ & $6.5 \pm 1.8 \dagger$ \\
$24: 0$ & $1.0 \pm 0.1$ & $0.7 \pm 0.1 \dagger$ \\
$24: 1 \mathrm{n}-9$ & $0.62 \pm 0.04$ & $0.90 \pm 0.09 \dagger$ \\
$22: 6 \mathrm{n}-3$ & $3.1 \pm 0.4$ & $2.2 \pm 0.5 \dagger$ \\
$18: 1 \mathrm{n}-9 / 18: 2 \mathrm{n}-6$ & $0.17 \pm 0.02$ & $3.2 \pm 1.3 \dagger$ \\
$20: 3 \mathrm{n}-9 / 20: 4 \mathrm{n}-6$ & $0.01 \pm 0.0$ & $1.1 \pm 0.5 \dagger$ \\
$20: 4 \mathrm{n}-6 / 22: 6 \mathrm{n}-3$ & $4.7 \pm 0.6$ & $2.9 \pm 0.3 \dagger$ \\
$\mathrm{n}-6 / \mathrm{n}-3$ & $12.4 \pm 1.4$ & $6.0 \pm 0.9 \dagger$ \\
\hline
\end{tabular}

Values are mean $\pm \mathrm{SD}$.

Results with $*$ and $\dagger$ are significantly different, $p<0.05$ and $p<0.005$, respectively, from control values. wk of lactation to $2.0 \pm 0.3 \mathrm{ng} / \mathrm{mL}$ just before weaning ( $p<$ 0.05 ; Fig. 1). Dams receiving the EFAD diet showed a significant increase in milk leptin levels, from $2.4 \pm 0.3 \mathrm{ng} / \mathrm{mL}$ in the first week to $3.6 \pm 0.9 \mathrm{ng} / \mathrm{mL}$ in the third week of lactation $(p<0.05)$. As a result, milk leptin levels did not differ significantly between the control and the EFAD groups at $1 \mathrm{wk}$ of lactation, but at $3 \mathrm{wk}$ of lactation the dams fed the EFAD diet had higher milk leptin levels compared with control dams $(p<0.05)$.

Leptin mRNA expression in adipose tissue. Leptin expression in inguinal adipose tissue was detected as a 244-bp band. The identity of the PCR product was verified by restriction enzyme digestion with $A g e \mathrm{I}$, which gave the expected pattern of two bands at $140 \mathrm{bp}$ and $104 \mathrm{bp}$ (data not shown). The leptin mRNA expression in the inguinal WAT of pups from the EFAD dams was similar to that of the control pups at 1 wk of age (Fig. 2). At 3 wk of age, however, the levels of the leptin mRNA were significantly lower in the WAT of pups receiving the EFAD diet compared with those in the control group.

\section{DISCUSSION}

Our study showed that maternal dietary deficiency of EFA lead to reduced growth of adipose tissue, lowered inguinal WAT leptin mRNA expression, and lowered serum leptin levels in suckling pups. We also observed that maternal dietary EFAD was associated with an increase of milk leptin levels and a concomitant reduced growth rate of their pups.

Total milk lipids of the lactating control rats contained relatively high levels of SFA and the LCPUFAs, 20:4(n-6) and 22:6(n-3), and did not reflect the FA composition of their diet. The type of dietary fat is known to determine the FA composition of milk lipids both directly (23) and indirectly, by influencing de novo synthesis of FA within the mammary gland or other tissues (24) and also by mobilization of lipids from adipose tissue stores (25). Recent studies have shown that $30 \%$ of milk EFA are derived directly from the maternal diet whereas the major part of milk EFA are derived from maternal tissues (26). Because the EFAD-fed dams did not receive an adequate amount of EFA from their diet, they produced milk depleted in EFA and enriched in medium-chain SFA already at the first week of lactation. There was a pronounced reduction of PUFA levels in the milk lipids from lactating EFAD-fed rats after $3 \mathrm{wk}$ of lactation. This subsequently influenced the EFA composition of the serum PL in the pups, decreasing the EFA levels at the third week of age. The pups suckling dams fed the EFAD diet had suppressed serum leptin levels during the whole suckling period compared with the control pups.

It is generally accepted that plasma leptin levels correlate with adipose tissue mass in adult rodents (27). However, such factors as high-fat diet and dietary PUFA may influence circulating leptin concentrations by a mechanism unrelated to changes in adipose tissue mass $(15,28)$. Less is known about regulation of plasma leptin levels in very young animals. Plasma leptin levels in rodent pups change independently of fat 
Table 4. Body weight and length, weight of WAT, and serum leptin concentration of control and EFAD pups at 3 wk of age

\begin{tabular}{|c|c|c|c|c|c|c|}
\hline & \multicolumn{3}{|c|}{ Control diet } & \multicolumn{3}{|c|}{ EFAD diet } \\
\hline & $1 \mathrm{wk}$ & $2 \mathrm{wk}$ & $3 \mathrm{wk}$ & $1 \mathrm{wk}$ & $2 \mathrm{wk}$ & $3 \mathrm{wk}$ \\
\hline Weight (g) & $11.2 \pm 1.5$ & $19.4 \pm 4.2$ & $41.4 \pm 4.5$ & $11.3 \pm 0.9$ & $19.0 \pm 2.4$ & $32.9 \pm 3.1 \dagger$ \\
\hline WAT (mg) & $90.1 \pm 37.5$ & $136.7 \pm 58.3$ & $446.1 \pm 144.4$ & $48.2 \pm 24.3 *$ & $83.3 \pm 20.6^{*}$ & $276.5 \pm 102.7^{*}$ \\
\hline $\begin{array}{l}\text { WAT } \\
\text { (mg/g } \\
\text { body } \\
\text { weight) }\end{array}$ & $8.3 \pm 3.2$ & $6.9 \pm 2.6$ & $10.8 \pm 3.5$ & $4.7 \pm 2.3^{*}$ & $4.4 \pm 0.7^{*}$ & $8.3 \pm 2.5$ \\
\hline $\begin{array}{l}\text { Leptin } \\
\qquad(\mathrm{ng} / \mathrm{mL})\end{array}$ & $1.3 \pm 0.7$ & $1.9 \pm 1.0$ & $2.3 \pm 0.7$ & $0.4 \pm 0.3 \dagger$ & $0.6 \pm 0.2 \dagger$ & $1.4 \pm 0.9^{*}$ \\
\hline
\end{tabular}

Values are mean \pm SD.

Results with $*$ and $\dagger$ are significantly different, $p<0.05$ and $p<0.005$, respectively, from control values.

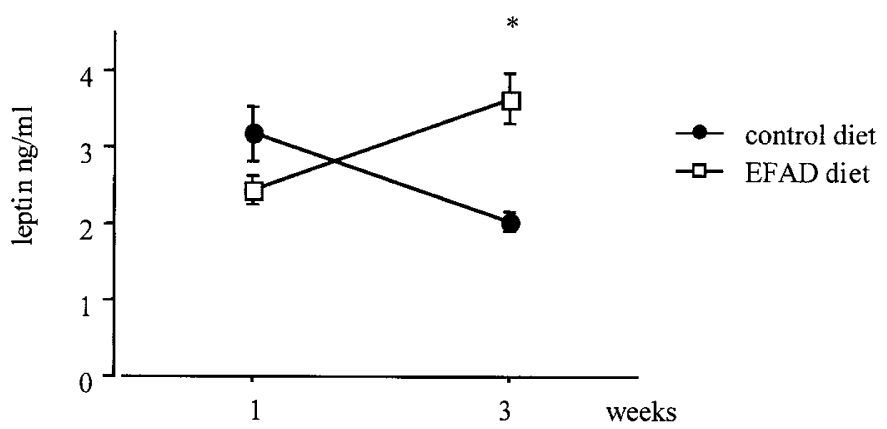

Figure 1. Effect of EFAD diet on milk leptin levels (mean \pm SEM) in rat dams during the lactation period (each point represents $6-9$ animals). Results with $*$ are significantly different from control values $(p<0.05)$.

mass $(8,29)$ and might also be influenced by leptin content in breast milk (19).

At present, the role of milk-derived leptin in pups is not clear. Milk leptin originates both from the maternal blood stream (19) and from local production and secretion by the mammary gland (11). Oral administration of recombinant human leptin mixed in milk to suckling rat pups led to a timedependent increase of human leptin in the serum (19). Thus, the amount of transferred leptin via milk may induce changes in the leptin levels of the offspring. It is possible that the significantly lower serum leptin levels in the EFAD pups could be caused by a lowered leptin content in the milk. Leptin levels were increased from wk 1 to wk 3 in the milk of the EFAD dams but decreased in the control dams. Consequently, at the third week of lactation, leptin levels in the milk obtained from EFAD-fed dams were significantly higher compared with control dams. Thus, milk leptin was increased whereas serum leptin was decreased in the pups of the dams fed the EFAD diet. Thus it is reasonable to assume that reported serum leptin levels did not reflect a contribution from breast milk but reflected adipose production of leptin. In addition, we have previously shown that dams receiving the EFAD diet had decreased serum leptin levels compared with control dams (18). It therefore seems that dietary FA might affect leptin production differently in mammary epithelial cells compared with adipocytes in lactating rats.

Inguinal adipose tissue is the major fat depot and the main source of serum leptin in rat pups during the suckling period (8). The inguinal WAT depots were well developed in pups
A.

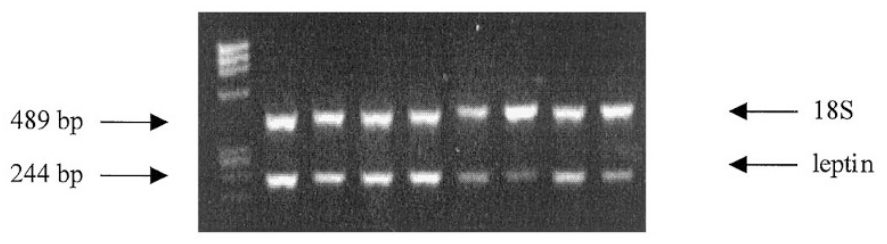

B.

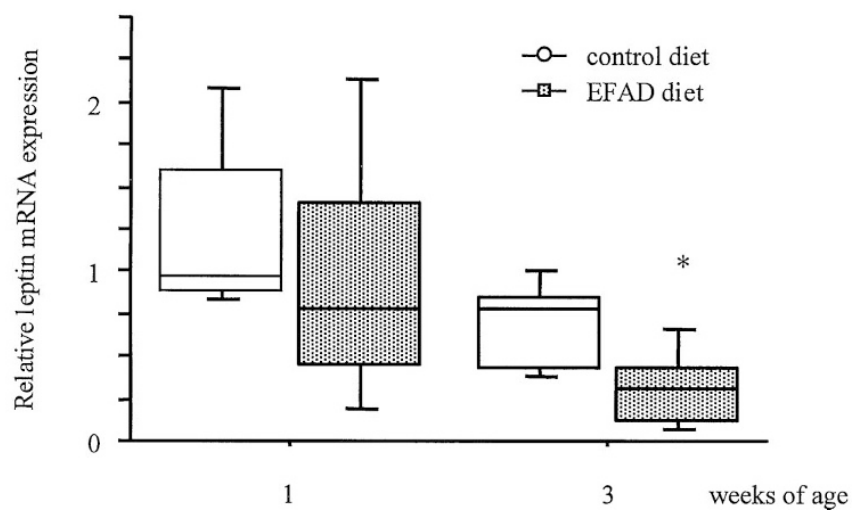

Figure 2. $A$, aliquots of the PCR products for each individual rat (lanes $1-4$ indicate control, lanes 5-8 indicate EFAD group) were run on $2 \% \mathrm{EtBr}$ agarose gel and were subsequently visualized and quantified using IPLab Gel Scientific Image processing. $M$, marker (OX174 RF DNA/HaeIII fragments). $B$, effect of EFAD diet on relative expression of leptin mRNA in rat inguinal WAT during the suckling period (each group represents 6-9 animals). The expression level of leptin was normalized to that of 18S RNA. Results are expressed as box plots that indicate median and lower and upper quartiles. Whiskers show the 5th and 95th percentiles. Results with* are significantly different from control values $(p<0.05)$.

suckling the control dams. Feeding the EFAD diet resulted in lower body weight, lower inguinal WAT mass, and low serum leptin levels. Those variables could be affected by a decrease in caloric intake caused by changes either in feeding frequency or amount of consumed milk. However, 
both caloric intake and metabolic rate of suckling pups are hard to evaluate with precision. We indirectly evaluated whether caloric intake was different between pups from the two diet groups. All dams were fed ad libitum, there were no differences in body weight during lactation between the groups, and the number of pups per litter was equal in both diet groups. Furthermore, there were no differences in serum glucose and corticosterone levels in the rat pups from the two diet groups (18), which reflects the nutritional status in suckling rat pups (30). In addition, rat pups that are handreared with artificial milk deficient in EFA have lower body weight compared with control pups receiving the same amount of milk sufficient in EFA, despite equal caloric intake (31). This suggests that the FA composition of milk per se could be responsible for the changes in body weight and fat deposition in the EFAD pups.

Adipose tissue growth in the suckling rat is determined by both an initial adipocyte hypertrophy and by a later increase in fat cell numbers (23). We observed that lowered serum leptin levels in suckling EFAD pups were related to reduced growth of adipose tissue that might reflect a decrease in adipocyte cell size or number. We found no differences in leptin mRNA levels in the WAT of the EFAD and control pups at wk 1. At the third week of age, besides reduced WAT mass, leptin mRNA expression was suppressed in the WAT from EFAD pups. This might reflect down-regulation of the leptin gene.

Deficiency of EFA leads to growth retardation both in animals and humans, and a correlation between LCPUFA status and early growth has been reported (32). During early life a growth-promoting effect of LCPUFA may be related to its structural function in membrane lipids or to its role as an eicosanoid precursors (32). However, the growth-promoting effect of LCPUFA might be associated with its role in leptin production. Leptin also has been shown to act as a growth factor and to increase proliferation and differentiation in various tissues in vivo and in vitro $(33,34)$, promote angiogenesis (35), and affect bone mineralization (36). It is possible that the effect on body weight and length of the EFAD pups that was observed during the third week could be related both to the decreased levels of LCPUFA and the decreased levels of leptin.

There is increasing evidence that prenatal and postnatal nutrition may modulate early development and program adult diseases in mammals, but the related mechanisms remain to be defined. In the early postnatal period, leptin plays an important role in the regulation of development and function of the neuroendocrine axis (29), and leptin deficiency during this sensitive period might have permanent effects on later health. Both EFA deficiency (37) and low leptin levels (38) have been shown to be associated with reduced growth in early life in humans. Our data, showing that an adequate intake of EFA during the perinatal period is important for maintenance of circulating leptin levels, might be relevant also in human neonates. Variation in the dietary intake of EFA during pregnancy and lactation might program the development and later health via leptin-associated mechanisms.
Acknowledgment. The authors thank Berit Holmberg for excellent technical assistance.

\section{REFERENCES}

1. Lucas A 1998 Programming by early nutrition: an experimental approach. J Nutr 128:401S-406S

2. Shaheen SO, Sterne JA, Montgomery SM, Azima H 1999 Birth weight, body mass index and asthma in young adults. Thorax 54:396-402

3. Hales CN, Barker DJ, Clark PM, Cox LJ, Fall C, Osmond C, Winter PD 1991 Fetal and infant growth and impaired glucose tolerance at age 64. BMJ 303:1019-1022

4. Robillard PY, Christon R 1993 Lipid intake during pregnancy in developing countries: possible effect of essential fatty acid deficiency on fetal growth. Prostaglandins Leukot Essent Fatty Acids 48:139-142

5. Lee EJ, Simmer K, Gibson RA 1993 Essential fatty acid deficiency in parenterally fed preterm infants. J Paediatr Child Health 29:51-55

6. Foreman-van Drongelen MM, Zeijdner EE, van Houwelingen AC, Kester AD, Al MD, Hasaart TH, Hornstra G 1996 Essential fatty acid status measured in umbilical vessel walls of infants born after a multiple pregnancy. Early Hum Dev 46:205-215

7. Matsuda J, Yokota I, Iida M, Murakami T, Yamada M, Saijo T, Naito E, Ito M, Shima K, Kuroda Y 1999 Dynamic changes in serum leptin concentrations during the fetal and neonatal periods. Pediatr Res 45:71-75

8. Rayner DV, Dalgliesh GD, Duncan JS, Hardie LJ, Hoggard N, Trayhurn P 1997 Postnatal development of the $o b$ gene system: elevated leptin levels in suckling fa/fa rats. Am J Physiol 273:R446-R450

9. Ahima RS, Flier JS 2000 Leptin. Annu Rev Physiol 62: 413-437

10. Senaris R, Garcia-Caballero T, Casabiell X, Gallego R, Castro R, Considine RV, Dieguez C, Casanueva FF 1997 Synthesis of leptin in human placenta. Endocrinology 138:4501-4504

11. Aoki N, Kawamura M, Matsuda T 1999 Lactation-dependent down regulation of leptin production in mouse mammary gland. Biochim Biophys Acta 1427:298-306

12. Hassink SG, de Lancey E, Sheslow DV, Smith-Kirwin SM, O'Connor DM, Considine RV, Opentanova I, Dostal K, Spear ML, Leef K, Ash M, Spitzer AR, Funanage VL 1997 Placental leptin: an important new growth factor in intrauterine and neonatal development? Pediatrics 100:E1-6

13. Grunfeld C, Zhao C, Fuller J, Pollack A, Moser A, Friedman J, Feingold KR 1996 Endotoxin and cytokines induce expression of leptin, the $o b$ gene product, in hamsters. J Clin Invest 97:2152-2157

14. Mooradian AD, Chehade J, Hurd R, Haas MJ 2000 Monosaccharide-enriched diets cause hyperleptinemia without hypophagia. Nutrition 16:439-441

15. Cha MC JP 1998 Dietary fat type and energy restriction interactively influence plasma leptin concentration in rats. J Lipid Res 39:1655-1660

16. Mantzoros CS, Prasad AS, Beck FW, Grabowski S, Kaplan J, Adair C, Brewer GJ 1998 Zinc may regulate serum leptin concentrations in humans. J Am Coll Nutr $17: 270-275$

17. Trottier G, Koski KG, Brun T, Toufexis DJ, Richard D, Walker CD 1998 Increased fat intake during lactation modifies hypothalamic-pituitary-adrenal responsiveness in developing rat pups: a possible role for leptin. Endocrinology 139:3704-3711

18. Korotkova M, Gabrielsson B, Hanson L, Strandvik B 2001 Maternal essential fatty acid deficiency depresses serum leptin levels in suckling rat pups. J Lipid Res 42:359-365

19. Casabiell X, Pineiro V, Tome MA, Peino R, Dieguez C, Casanueva FF 1997 Presence of leptin in colostrum and/or breast milk from lactating mothers: a potential role in the regulation of neonatal food intake. J Clin Endocrinol Metab 82:4270-4273

20. Folch JLM, Sloane-Stanley GH 1957 A simple method for the isolation and purification of total lipids from animal tissues. J Biol Chem 226:497-509

21. Holman RT 1960 The ratio of trienoic:tetraenoic acids in tissue lipids as a measure of essential fatty acid requirement. J Nutr 70:405-410

22. Jin L, Zhang S, Burguera BG, Couce ME, Osamwa RY, Kulig E, Lloyd RV 2000 Leptin and leptin receptor expression in rat and mouse pituitary cells. Endocrinology 141:333-339

23. Dugail I, Quignard-Boulange A, Dupuy F 1986 Role of adipocyte precursors in the onset of obesity induced by overfeeding in suckling rats. J Nutr 116:524-535

24. Grigor MR, Warren SM 1980 Dietary regulation of mammary lipogenesis in lactating rats. Biochem J 188:61-65

25. Larking PW, Nye ER 1975 The effect of dietary lipids on lipolysis in rat adipose tissue. Br J Nutr 33:291-297

26. Demmelmair H, Baumheuer M, Koletzko B, Dokoupil K, Kratl G 1998 Metabolism of $\mathrm{U}^{13} \mathrm{C}$-labeled linoleic acid in lactating women. J Lipid Res 39:1389-1396

27. Frederich RC, Hamann A, Anderson S, Lollmann B, Lowell BB, Flier JS 1995 Leptin levels reflect body lipid content in mice: evidence for diet- induced resistance to leptin action. Nat Med 1:1311-1314

28. Ainslie DA, Proietto J, Fam BC, Thorburn AW 2000 Short-term, high-fat diets lower circulating leptin concentrations in rats. Am J Clin Nutr 71:438-442

29. Ahima RS, Prabakaran D, Flier JS 1998 Postnatal leptin surge and regulation of circadian rhythm of leptin by feeding: implications for energy homeostasis and neuroendocrine function. J Clin Invest 101:1020-1027

30. Boxwell J, Ayson P, Ramenofsky M 1995 Growth and metabolic parameters in pups of undernourished lactating rats. Physiol Behav 57:469-475

31. Dvorak B, Stepankova R 1992 Effects of dietary essential fatty acid deficiency on the development of the rat thymus and immune system. Prostaglandins Leukot Essent Fatty Acids 46:183-190 
32. Koletzko B, Braun M 1991 Arachidonic acid and early human growth: is there a relation? Ann Nutr Metab 35:128-131

33. Mikhail AA, Beck EX, Shafer A, Barut B, Gbur JS, Zupancic TJ, Schweitzer AC, Cioffi JA, Lacaud G, Ouyang B, Keller G, Snodgrass HR 1997 Leptin stimulates fetal and adult erythroid and myeloid development. Blood 89:1507-1512

34. Hardwick JC, Van Den Brink GR, Offerhaus GJ, Van Deventer SJ, Peppelenbosch MP 2001 Leptin is a growth factor for colonic epithelial cells. Gastroenterology 121:79-90

35. Bouloumie A, Drexler HC, Lafontan M, Busse R 1998 Leptin, the product of $O b$ gene, promotes angiogenesis. Circ Res 83:1059-1066
36. Reseland JE, Syversen U, Bakke I, Qvigstad G, Eide LG, Hjertner O, Gordeladze JO, Drevon C A 2001 Leptin is expressed in and secreted from primary cultures of human osteoblasts and promotes bone mineralization. J Bone Miner Res 16:1426-433

37. Crawford MA, Doyle W, Drury P, Lennon A, Costeloe K, Leighfield M 1989 n-6 and n-3 fatty acids during early human development. J Intern Med Suppl 225:159-169

38. Cinaz P, Sen E, Bideci A, Ezgu FS, Atalay Y, Koca E 1999 Plasma leptin levels of large for gestational age and small for gestational age infants. Acta Paediatr 88:753756 